\title{
Annex A
}

\section{List of Participants}

Member of the Scientific Committee/National delegate (SC); Invited Participant (IP); and Observer $(\mathrm{O})$

\author{
Alex Aguilar (IP) \\ Dept. Animal Biology \\ Faculty of Biology \\ University of Barcelona \\ Barcelona \\ SPAIN
}

Tel: $34-3-319-8959$

Fax: $3+-3-+11-0887$

e-mail: alexa@porthos.bio.ub.es

\section{Pierre Béland (IP)}

St. Lawrence National Institute of

Ecotoxicology

460 Champ-de-Mars \#504

Montreal, Quebec

CANADA

H2Y $1 B 4$

Tel: $1-514-499-3499$

Fax: 1-514-982-1788

e-mail: belandp@cam.org

Jonny Beyer (SC)

Laboratory UF Marine Molecular Biology

University of Bergen, $\mathrm{HiB}$

N-5020 Bergen

NORWAY

Tel: 47-5554-4375

Fax: 47-5554-4373

e-mail: jonny.beyer@lmm.uib.no

Arne Bjørge (SC)

Institute of Marine Research

PO Box 1870 Nordnes

N-5024 Bergen

NORWAY

Tel: 47-5523-8608

Fax: 47-5523-8617

e-mail: arnebj@imr.no
Jacob de Boer (IP)

RIVO-DLO

PO Box 68

1970 AB IJmuiden

THE NETHERLANDS

Tel: 31-255-564736

Fax: 31-255-564644

e-mail: jacob@rivo.dlo.nl

Jan P. Boon (IP)

Netherlands Institute for Sea Research

(NIOZ)

PO Box 59

1790 AB Den Burg

Texel

THE NETHERLANDS

Tel: 31-222-369466/369300

Fax: 31-222-319674

e-mail: boon@nioz.nl

Asunción Borrell (IP)

Dept. Animal Biology

Faculty of Biology

University of Barcelona

Diagonal 645

08028 Barcelona

SPAIN

Tel: $34-3-319-8959$

Fax: 34-3-411-0877

e-mail: assump@porthos.bio.ub.es

Bram Brouwer (IP)

Department of Toxicology

Agricultural University

PO Box 8000

6700 EA Wageningen

THE NETHERLANDS

Tel: $31-317-48397 / 482137$

Fax: 31-317-484931

e-mail:

bram.brouwer@algemeen.tox.wau.nl 
Kevin Brown (IP)

Centre for Overseas Research and

Development

Department of Geography

University of Durham

Science Laboratories

South Road

Durham

DHL 3LE

UK

Tel: 44-191-3742495

Fax: 44-191-3742495

e-mail: kevin.brown@durham.ac.uk

Robert L. Brownell, Jr (SC)

Southwest Fisheries Science Center

PO Box 271

La Jolla

California 92038

USA

Tel: 1-619-546-7165

Fax: 1-619-546-5653

e-mail: brownell@caliban.ucsd.edu

Florence Caurant (IP)

Institut D'Ecologie Appliquee

Universite Catholique de L'Ouest

3, Place Andre Leroy B.P. 808

49008 Angers Cedex 01

FRANCE

Tel: $33-41-81-66-17$

Fax: 33-41-81-66-74

B. Clausen (IP)

Environmental Investigation Agency

Min. of Environment

Fredriksbergvej 399 Box 358

4000 Roskilde

DENMARK

Tel: $45-46-301200$

Fax: 45-46-301114

Theo Colborn (IP)

World Wildlife Fund

1250 Twenty Fourth Street NW

Washington, DC 20037

USA

Tel: 1-202-778-9643

Fax: 1-202-293-9211

e-mail: colborn+r\%wwfus@mcimail.com
A. Morrie Craig (IP)

College of Vet. Medicine

Oregon State University

Corvallis OR 97331

USA

Tel: 1-503-737-3036

Fax: 1-503-737-0502

Greg Donovan (SC)

International Whaling Commission

The Red House

135 Station Road

Histon, Cambridge

CB4 4NP

UK

Tel: 44-1223-233971

Fax: 44-1223-232876

e-mail: gregiwc@compuserve.com

John Frizell (O)

5 Lancaster Street

Lewes

E. Sussex

BN7 2PX

UK

Tel: 44-1273-476839

Fax: 44-1273-471431

Yoshihiro Fujise (SC)

The Institute of Cetacean Research

Tokyo-Suisan BIdg

4-18, Toyomi-cho

Chuo-ku, Tokyo 104

JAPAN

Tel: $81-3-3536-6521$

Fax: 81-3-35.36-6.522

Bjorn Munro Jenssen (SC)

Department of Zoology

University of Trondheim

N-7055 Dragvoll

NORWAY

Tel: 47-7359-6267

Fax: 47-7359-1309

e-mail: bmj@alfa.avh.unit.no 
Paul D. Jones (IP)

ESR Environmental

Wellington Science Center

PO Box 30-547

Lower Hutt

NEW ZEALAND

Tel: 64-4-570-1555 ext 8623

Fax: 64-4-569-4500

e-mail: jonesp\%ehadmin@lincoln.cri.nz

So Kawaguchi (SC)

National Research Institute of Far Seas

Fisheries

5-7-1 Orido

Shimizu 424

JAPAN

Tel: $81-5+3-34-0715$

Fax: 81-543-35-9642

e-mail: kawaso@enyo.affrc.go.jp

Seamus Kennedy (IP)

Veterinary Sciences Division

Dept. of Agriculture for N. Ireland

Stoney Road

Stormont

BELFAST

BT4 3SD

Tel: 44-1232-525701

Fax: 44-1232-525767

Jarle Klungsøyr (SC)

Institute of Marine Research

PO Box 1870 Nordnes

5024 Bergen

NORWAY

Tel: $47-5523-8500$

Fax: 47-5523-8584

e-mail: jarle.klungsoyr.@imr.no

Margaret (Peggy) Krahn (IP)

NOAA/NMFS/E.C. Division

2725 Montlake Blvd E

Seattle, WA 98112

USA

Tel: 1 -206-860-3326

Fax: 1-206-860-3335

e-mail: pkrahn@sci.nwfsc.noaa.gov
Robin J. Law (IP)

Ministry of Agriculture, Fisheries and

Food

Fisheries Laboratory

Remembrance Avenue

Burnham on Crouch

Essex

CM0 8HA

UK

Tel: $44-1621-782658$

Fax: 44-1621-784989

e-mail: r.j.law@dfr.maff.gov.uk

Daniel Martineau (IP)

Dept. Pathology

College of Veterinary Medicine

University of Montreal

Saint-Hyacinthe P.Q.

J2S 7C6

CANADA

Tel: 514-773-8521

Fax: 1-514-7788113

e-mail: martinea@ere.umontreal.ca

Michael Moore (IP)

Biology Department

Redfield 342

Woods Hole Oceanographic Institution

Woods Hole

MA 02543-1049

USA

Tel: 1-508-289-3228

Fax: 1-508-457-2169

e-mail:mmoore@aqua.whoi.edu

Nils Øien (SC)

Institute of Marine Research

PO Box 1870 Nordnes

N-5024 Bergen

NORWAY

Tel: 47-5523-8605

Fax: 47-5523-8617

e-mail: nils@imr.no

Torger Oritsland (SC)

c/o Marine Mammal Division

Institute of Marine Research

PO Box 1870 Nordnes

N-5024 Bergen

NORWAY

Tel: 47-5523-8611

Fax: 47-5523-8387 
Thomas O'Shea (IP)

National Biological Service

Midcontinent Ecological Science Center

4512 McMurray Ave

Fort Collins

Colorado 80525-3400

USA

Tel: 1-303-226-9397

Fax: 1-303-226-9230

e-mail: osheat@mail.fws.gov

Teresa Pastor (IP)

Dept. Animal Biology

University of Barcelona

Av. Diagonal 645

08028 Barcelona

SPAIN

Tel: $34-3-319-8959$

Fax: 34-3-411-0887

e-mail: pastor@porthos.bio.ub.es

David Peakall (IP)

17 St. Mary's Road

Wimbledon

London

SW19 7BZ

UK

Tel: 44-181-9470573

Fax: 44-181-9468785

Sian Pullen (IP)

WWF UK

Panda House

Weyside Park

Catteshall Lane

Godalming

Surrey, GU7 1XR

UK

Tel: 44-1483-426444

Fax: 44-1483-426409

Peter J.H. Reijnders (SC)

Institute for Forestry and Nature Research

Dept. Aquatic Ecology

PO Box 167

1790 AD Den Burg

THE NETHERLANDS

Tel: $31-222-369700$

Fax: 31-222-319235

e-mail: p.j.h.reijnders@ibn.dlo.nl
Kate Sanderson $(\mathrm{O})$
NAMMCO
University of Troms $\emptyset$
9007 Troms $\emptyset$
NORWAY
Tel: 47-7764-5903
Fax: 47-7764-5905
e-mail: kates@nammco.no

M.P. Simmonds (IP)

Whale and Dolphin Conservation Society

Alexander House

James Street West

Bath

BA1 2BT

UK

Tel: 44-1225-334511

Fax: 44-1225-480097

Janneche Utne Skåre (SC)

Department of Toxicology and Chemistry

Central Veterinary Laboratory

PO Box 8156 Dep.

0033 Oslo

NORWAY

Tel: 47-2296-4500

Fax: 47-2296-4850

Michael Smolen (O)

World Wildlife Fund

1250 Twenty-Fourth St. NW

Washington DC 20037-1175

USA

Tel: 1-202-861-8354

Fax: 1-202-293-9211

e-mail: smolen+r\%wwfus@mcimail.com

John Stein (IP)

Environmental Conservation Division

Northwest Fisheries Science Center

2725 Montlake Blvd. E.

Seattle, WA 98112-2097

USA

Tel: 1-206-860-3330

Fax: 1-206-860-3335

e-mail: jstein@sci.nwfsc.noaa.gov 
Allan Thornton $(\mathrm{O})$

Environmental Investigation Agency

2 Pear Tree Court

London

UK

Tel: 44-171-4907040

Fax: 4+171-4900436

Donald Tillitt (IP)

US Dept. of Interior

National Biological Service

4200 New Haven Road

Columbia, MO 65201

USA

Tel: 1-314-875-5399

Fax: 1-314-876-1896

e-mail: tillittd@mail.fws.gov
Lars Walløe (SC)

Department of Physiology

University of Oslo

PO Box 1103 Blindern

0317 Oslo

NORWAY

Tel: 47-2285-1218

Fax: 47-2285-1249

e-mail: lars.walloe@basalmed.uio.no

Geir Wang-Anderson $(\mathrm{O})$

Greenpeace Norway

Post Box 6803 St. Olavsplass

0130 Oslo

NORWAY

Tel: 47-2220-5101

Fax: 47-2220-5114

e-mail: geir.wang-andersen@green2.dat.de 


\section{Annex B}

\section{Agenda}

1. Introduction (including arrangements for Workshop)

2. Adoption of Agenda

3. Keynote presentations

3.1 Individual variation in contaminant levels

3.2 Xenobiotics and metabolism

3.3 Cancer in cetaceans, a potential biomarker of environmental contamination

3.4 Epidemiology/epizootics and contaminants

3.5 Significance and potential of biomarkers in marine mammal toxicology

4. Effects of chemical pollution on cetaceans

4.1 Direct effects

4.1.1 Lethal effects

4.1.2 Sub-lethal effects

4.1.2.1 Diseases

4.1.2.2 Reproduction and early development

4.1.2.3 Immune suppression

4.1.2.4 Cancer induction and mutagenic effects

4.1.2.5 Behaviour

4.1.2.6 Epizootics

\subsection{Indirect effects}

5. Research implications

5.1 Consideration of synergistic/cumulative effects

5.2 Exotic compounds

5.3 Adequacy of present monitoring

5.3.1 Sources of samples

5.3.2 Biomarkers

5.3.3 Biological variables

5.3.4 Pathology examinations

5.3.5 Specimen banking

5.4 Further evaluation of the relationship between toxic burden and impacts

5.5 Risk and hazard assessment techniques

5.6 Trends in global contamination

5.7 Identification of additional areas of concern

5.8 Review of submitted proposals

6. Implications for the future work of the IWC Scientific Committee

7. Recommendations

8. Publications

9. Adoption of Report 


\section{Annex C}

\section{List of Documents}

\section{$\mathrm{SC} / \mathrm{M95}$}

SC/M95/P1. BOON, J.P. Monitoring concentrations of organochlorines, and biochemical and immunological effects in samples of living marine mammals. An introductory note on the possibilities.

SC/M95/P2. MOORE, M.J., MILLER, C.A., WHITE, R.D., SHEA, D., WEISBROD, A.V. and STEGEMAN, J.J. Histological and cytochrome P4501A expression in tissues of pilot whales, Globicephala melaena, stranded on Cape Cod, MA USA.

SC/M95/P3. CAURANT, F. Cadmium and mercury in pilot whales: physico-chemical forms of storage and potential hazard to the species.

SC/M95/P4. COLBORN, T. and SMOLEN, M. An epidemiological analysis of persistent organochlorine contaminants in large cetaceans.

SC/M95/P5. CRAIG, A.M., ORPIN, C.G. and BLYTHE, L.L. Biotransformation of marine pollutants, particularly crude oil alkanes, by forestomach bacteria from the bowhead whale. [Research Proposal.]

SC/M95/P6. AGUILAR, A., BORRELL, A. and PASTOR, T. Factors affecting variability of persistent pollutant levels in cetaceans.

SC/M95/P7. BORRELL, A. Summary of temporal trends in pollutant levels observed in marine mammals.

SC/M95/P8. BROUWER, A. Metabolism of xenobiotics in laboratory animals and wildlife species: potential impact on physiology and health.

SC/M95/P9. PEAKALL, D.B. Biomarkers as pollution indicators with special reference to cetaceans.

SC/M95/P10. MARTINEAU, D., LAIR, S., DE GUISE, S. and BELAND, P. Cancer in cetaceans, a potential biomarker for environmental contamination.

SC/M95/P11. SIMMONDS, M.P. Marine mammal mass mortality events: Environmental influences and science.

SC/M95/P12. DONOVAN, G.P. Pollution references on the IWC database.

SC/M95/P13. TANABE, S., AONO, S., FUJISE, Y., KATO, H. and TATSUKAWA, R. Persistent organochlorine residues in the Antarctic minke whale, Balaenoptera acutorostrata.

SC/M95/P14. FISHERIES AGENCY GOVERNMENT OF JAPAN. Project of global environment monitoring with fishing vessel network. 
SC/M95/P15. KENNEDY, S. Morbillivirus epizootics in aquatic mammals.

\section{$\mathrm{SC} / 46$}

SC/46/O 8. REIJNDERS, P.J.H. Contaminants and cetaceans: Reasons for concern?

SC/46/O 12. JONES, P.D., HANNAH, D.J., BUCKLAND, S.J., VAN MAANEN, T., LEATHEM, S.V., DAWSON, S., SLOOTEN, E., VAN HELDEN, A. and DONOGHUE, M. Planar chlorinated hydrocarbons in New Zealand marine mammals.

SC/46/O 14. MOSCROP, A. and SIMMONDS, M.P. The significance of pollution for marine cetaceans.

SC/46/O 16. BROWN, K. Requirements for a comprehensive assessment of pollution in cetaceans: quantification, evaluation and absolute threat of pollutants.

SC/46/O 20 (revised). BOWLES, D. An overview of the concentrations and effects of heavy metals in cetacean species.

SC/46/RP4. CAURANT, F., BLOCH, D., MOREAU, A., BALLAN-DUFRANCAIS, C. and ALGOET, M. Histo-pathology of kidney and liver tissues of the pilot whales off the Faroe Islands, related with high levels of cadmium and mercury. [Research Proposal.] 


\section{Annex D}

\section{Glossary}

Aromatic hydrocarbon (Ah) receptor. A protein that binds dioxins, dibenzofurans, non-ortho and mono-ortho PCBs, and 4 and 5 ring hydrocarbons.

Assays. Procedure for measurement or identification.

Biomarker. A biological response to a chemical or chemicals that give a measure of exposure and sometimes, also of toxic effect.

PCB Congeners. One of the 201 chemical forms of the PolyChlorinated Biphenyls. These are identified by numbers, e.g. OH-PCB-77, hydroxylated polychlorinated biphenyl, number 77.

Cytochrome P450 1A (CYP.1A). An enzyme found in epithelia and endothelia, that is induced by and metabolises dioxin, dibenzofurans, some PCBs, and 4 and 5 ring hydrocarbons. The protein concentration is commonly measured as a biomarker for the exposure and effect of those compounds.

DNA adducts. Covalent binding of pollutants, especially the polynuclear aromatic hydrocarbons (PAHs), to DNA. This clearly indicates exposure of the organism to the pollutant.

Endocrine disruptor. Any compound that interacts with reproductive physiology to alter normal expression of sexually dimorphic form and/or function.

Ethoxyresorufin-0-deethylase (EROD). A model substrate for metabolism by CYP-1A. The EROD activity is used in conjunction with CYP-1A as a biomarker of exposure to and effect of $\mathrm{Ah}$ receptor activating compounds.

Halogenated aromatic hydrocarbons (HAHs). Synthetic compounds containing chlorine, fluorine or bromine atoms, such as PCBs, pesticides and brominated fire retardants.

Hazard assessment. Estimation of potential risk.

Hepalc1c7. Liver tumour cell line.

Immunosuppression. A measureable alteration in any component(s) of the immune system that is likely to result in increased susceptibility to disease.

Mixed function oxidases (MFOs). A group of enzymes that are capable of metabolising a wide range of natural and unnatural chemicals. The function of these enzymes is to increase excretion of potentially harmful chemicals, but in the case of man-made compounds the metabolites may be more toxic than the original compound.

OH-PCB-77. Hydroxilated polychlorinated biphenyl, number 77 .

Persistent induction of biotransformation enzymes. Continous triggering of metabolisation enzymes. 
Polychlorinated biphenyls (PCBs). Synthetic compounds used for electrical capacitors in the 1950 s to 1970 s.

Polycyclic aromatic hydrocarbons (PAHs). Large groups of naturally occurring aromatic compounds containing two or more benzene rings fused together. Also, oil compounds derived directly (petrogenic) or indirectly via combustion (pyrogenic). Some of these compounds, such as benzo(a)pyrene, are known carcinogens.

Risk assessment. Estimation of extent of risk.

Residue levels. Concentrations of contaminants in substrate (e.g. soil, fluid, tissue).

$\mathbf{T}_{4}$-binding competition on TTR. Hepatic thyroxine binding competition on transthyretin.

Xenobiotics. Foreign substances to a living organism (e.g. contaminants).

\section{ABBREVIATIONS OF CHEMICAL COMPOUNDS}

3,3',4,4'-TeCB - tetrachlorobiphenyl.

CPs - chlorinated paraffins.

HCB - hexachlorobenzene.

HCHs - hexachlorocyclohexanes.

MSF - methylsulphate.

MSF-PCBs - methylsulphate-PCBs.

$\mathrm{OC}$ - organochlorines.

$\mathrm{OH}$ - organohalogens.

OH-PCBs - hydroxy-PCBs.

PAH - polycyclic aromatic hydrocarbons.

PBBs - polybrominated biphenyls.

PBDEs - polybrominated diphenylethers.

PCBs - polychlorinated biphenyls.

PCDDs - polychlorinated dibenzo-p-dioxins.

PCDEs - polychlorinated diphenylethers.

PCDFs - polychlorinated dibenzofurans.

PCNs - polychlorinated naphthalenes.

PCTs - polychlorinated terphenyls.

TBT - tributyl tin.

TCP - tris (G-chlorophenyl) methanol.

TCPMe - tris (G-chlorophenyl) methane.

TPT - triphenyl tin. 


\title{
Annex E
}

\section{Priorities in Pathology}

\author{
D. Martineau
}

\section{INTRODUCTION}

The following protocol is intended to further research into the chronic toxicity of organochlorinated compounds (OC) in cetaceans. OC toxicity has been well documented in domestic and laboratory animals. These compounds are known to induce squamous metaplasia of various glands (including mammary glands), to be oestrogenic and to produce mucous metaplasia in glandular stomachs and gastric erosions. A general record of each animal should be kept, including age, sex, reproductive status and, when available, the cause of death. Relevant OC contamination levels in the examined animal should be obtained. The severity and nature of the lesions might be ultimately correlated with OC levels in order to obtain a 'dose-response' relation.

It must be stressed that this protocol is not designed to determine the cause of death. Whenever possible, one should seek ideal conditions for post-mortem examination. These should include a complete, careful examination performed by trained personnel in an appropriate facility. In many field situations, these requirements cannot be fulfilled. Further information is provided in Kuiken and García Hartmann (1993).

\section{GENERAL PROCEDURE}

Thin, flat sections (approximately $3 \mathrm{~mm}$ thick, $1 \mathrm{~cm}$ wide and $2 \mathrm{~cm}$ long) should be cut and placed in neutral buffered $10 \%$ formalin.

Abnormalities: the size, shape, number and colour of any abnormalities should be described using simple terms, for example: 'a dozen randomly distributed, (1cm-diameter) round, dark red areas surrounded by a pale ( $2 \mathrm{~mm}$ thick) halo are present on the lower aspect of the heart'.

\section{SAMPLES REQUIRED FOR DETECTION OF CHRONIC OC TOXICITY}

Thyroid glands: cut gland parallel to its long axis, before fixation.

Lungs: total of six sections:

\begin{tabular}{|c|c|c|}
\hline Left lung: & $\begin{array}{l}\text { cranial } \\
\text { middle }\end{array}$ & Right lung: \\
\hline
\end{tabular}

Stomach: a section of the mucosa of each stomach. If ulcers are present, a section of the lesion and a section of normal bordering tissue.

Liver: three sections: middle and both sides.

Kidney: three sections of each: cranial, middle, caudal.

Adrenal glands: cut both glands parallel to their long axis, before fixation. 
Mammary glands: three sections of each: cranial, middle, caudal.

Uterus: three transverse sections of each uterine hom at various levels (total of six sections).

\section{REFERENCE}

Kuiken, T. and García Hartmann, M. 1993. Proceedings of the First European Cetacean Society Workshop on Cetacean Pathology: dissection techniques and tissue sampling. ECS Newsletter 17:1-39.

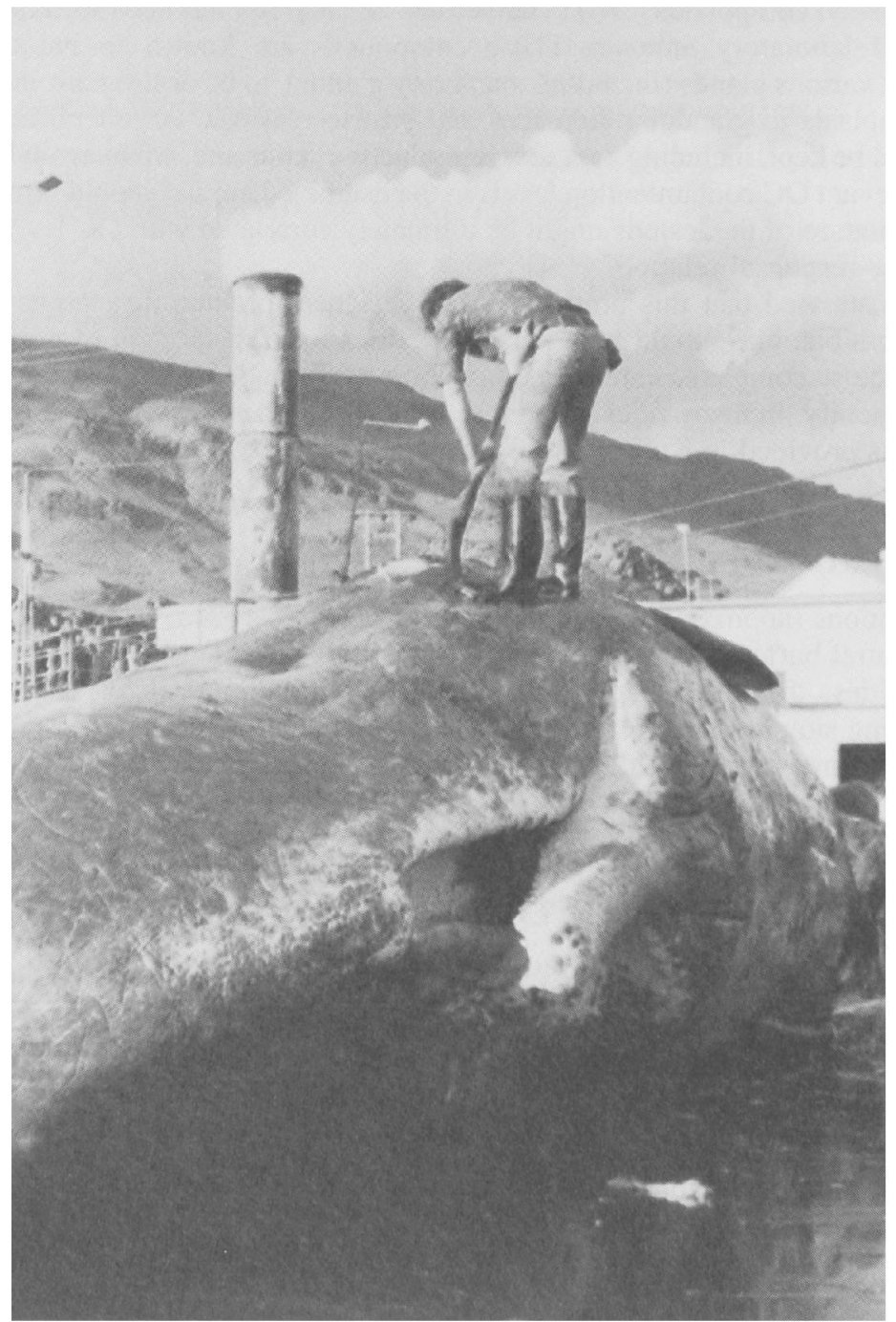

